\title{
A VÁROSMARKETING NÉHÁNY KÉRDÉSE
}

\author{
(Some Questions on City Marketing)
}

\author{
GORDOS TAMÁS
}

\section{Bevezetés}

A világgazdasági globalizáció hatására az országok csakúgy, mint térségeik és városaik versenyképességük fokozására kényszerülnek. Az EU tagországai ennek érdekében lépéseket tesznek a szorosabb integráció irányába, lebontva az áruk, a szolgáltatások, a tőke és a munkaerő szabad áramlása előtt álló akadályokat. Az országhatárok szerepe, a nemzeti szabályozás jelentősége egyre inkább háttérbe szorul. Megnövekszik viszont a regionális és települési szint jelentősége. A világgazdaság rendszerében meghatározóvá válik a transznacionális vállalatok szerepe, amelyek már egyre szabadabban választanak az országok, azok régiói és települései között. A városok, régiók és országok versenye a forrásokért és befektetőkért mind kiélezettebbé válik, már a minőségek kis különbségei meghatározóak lehetnek a cégek telephely-választási döntéseiben (Enyedi 1995).

Vannak városok, térségek, melyek fokozatosan veszítenek pozíciójukból, elvesztve a befektetők érdeklódését, míg mások elörelépnek a városok képzeletbeli rangsorán, és mind újabb befektetéseket illetve funkciókat képesek magukhoz vonzani. Pozícióik megtartása érdekében még a nyerteseknek is egyre nagyobb iramot kell diktálniuk. Hatékony módszerekre van szükségük, hogy megtartsák vagy visszaszerezzék elönyüket, hogy (újra)pozícionálhassák magukat. A városmarketing megoldani látszik ezeket a problémákat a fogyasztási cikkek marketingjéböl ismert marketing technikák segítségével.

Kérdéses azonban, hogy alkalmasak-e ezek az eszközök a fentebb vázolt célok elérésére, ha igen, milyen mértékben, és ha nem, miért nem tudnak megfelelni az elvárásoknak. Elemzésünkben a városfejlesztés ezen probléma-körére koncentrálunk, föbb összefüggéseiben vizsgálva a kérdést.

\section{A marketing szintjei}

A városok eltérő funkcióikból, népességszámukból, pozíciójukból, elhelyezkedésükböl fakadóan eltérő szinteken versenyeznek.

Az első szint a világvárosok exkluzív klubja (London, New York, Tokió). Tagjai - sokszinủ gazdasági hátterük mellett - a világ vezető pénzügyi központjai. A tőzsdék révén ők uralják a világkereskedelmet, és irányítják a világgazdaságot. Vannak új pályázók is a világ minden táján (pl. Frankfurt, Szingapúr), de az előbbiek pozíciója egyelöre biztosnak látszik. 
A második szinten azok a világvárosok találhatók, amelyek a társadalmi, gazdasági tevékenységek egyéb területein játszanak nemzetközi szerepet, mint pl. a számítástechnikában Los Angeles, San Francisco, Seattle, vagy a politikai hatalom szempontjából Washington, Moszkva, Peking, illetve a nagy társadalmi befolyással rendelkező szervezetek székhelyei: Brüsszel, Róma.

Ide sorolhatók a nagy multinacionális vállalatok székhelyei is: pl. Chicago, Hong Kong, Párizs, Atlanta (Rutheiser 1996). Nemcsak egy gazdasági, társadalmi tényezó szempontjából emelkednek ki, hanem gyakran ezek egész csoportja fölött gyakorolnak ellenőrzést, azonban az első három pénzügyi központ vezetö szerepét nem tudják átvenni.

A harmadik szintet a gazdasági és földrajzi perifériák metropoliszai, illetve a gazdasági magterületek nemzetközi jelentöségü városai alkotják, amelyeknek sikerült olyan funkciókat megszerezni, melyek hatása nemcsak a saját hátországukra, hanem annál nagyobb területre terjed ki. Ide lehet sorolni az első csoportból Sao Paulot, Buenos Aires-t, Johannesburgot és Szöult, illetve a második csoportból Torontót, Berlint vagy Barcelonát (Barta 1998).

A negyedik szintet a kisebb városok ,arénája” alkotja, amelyek a gazdaság egy szegmensére koncentrálva keresik azokat a niche-ket ${ }^{1}$, amelyeket a nagyok lefedetlenül hagynak, lehetőséget biztositva számukra nemzetközi szerep betöltésére. Helsinki és Reykjavik pozícióját, mint konferencia központokét új (önjelölt) pályázók igyekeznek veszélyeztetni, mint Birmingham vagy Oviedo (Visions... 1994, 191). Prága mint turisztikai, történelmi város építészeti örökségére alapoz („Arany Prága"), míg Stockholm kutatási és fejlesztési kapacitására épít.

Budapest kedvező földrajzi fekvéséböl adódó elönyökre építve igyekszik egyfajta kapu szerepet betölteni a fejlettebb nyugat-európai és a kevésbé fejlett kelet- és délkelet-európai térségek között (Enyedi 1998). Célja, hogy meghatározó regionális központtá váljon a Kárpát-medence térségében, kiterjesztve befolyási körét Keletés Délkelet-Európa irányába.

A verseny egyre élesebb, mivel a versenybe szállók száma a globalizációs folyamatok feltartóztathatatlan erősödésével egyre növekszik.

A szintek számát tovább növelve finomítani lehetne a felbontást, de ez a kis áttekintés is segítséget nyújthat a kiinduló helyzet felvázolásához, mivel a szintek különbözösége ellenére, a projektek meglehetös hasonlóságot mutatnak. A megcélzott csoportok és a befolyásolásuk érdekében igénybe vett technikák is sokban hasonlatosak egymáshoz.

\section{A marketing szemlélete}

A városoknak befektetésekre van szuikségük ahhoz, hogy jól szerepeljenek a városok versenyében. A „niche" megtalálása után pozitív képet kell kialakítaniuk magukról, „el kell adniuk” önmagukat. Azonosítaniuk kell tehát a fogyasztók (beruházók, helyi lakosság) igényeit annak érdekében, hogy az image-t ehhez igazítsák. 
A módszertan tisztán a fogyasztási cikkek marketingjéből származtatható, bár vannak bizonyos eltérések. Az eladandó térség vagy város sokkal komplexebb a hagyományos árucikkeknél. A város esetében az épített környezetet, a szolgáltatások bizonyos csoportját kell eladni, értékesíteni, amelyet nem ugyanúgy értékelnek az eladók és a vevők, gyakran nem is ugyanaz a kép jelenik meg a fejükben, mikor elvileg ugyanarról a településról beszélnek.

Nem történik tényleges adásvétel, legfeljebb bérlet, hasznositás vagy egyéb tranzakció (Enyedi 1995). Más termékeknél egyedi fogyasztás a jellemző, míg a térségek, városok esetében több tízezer vagy millió ember jelenik meg fogyasztóként, ennek megfelelően a lehetséges konfliktusok száma is megnövekszik. A „termék" ráadásul kevésbé rugalmas, nehezen lehet a fogyasztók igényeihez alakítani, illetve csak viszonylag hosszú időszak alatt, jelentős anyagi ráfordítások árán (Kozma 1999).

\section{A fogyasztói igények azonositása}

A termék eladásához a kereskedőnek pontos ismeretekkel kell rendelkeznie a piaci keresletröl, ezért felméréseket készítenek a fogyasztói igények megismerésére. Igaz ez a városmarketingre is. Az első feladat tehát a külsö és belső környezet elemzése, ennek egyik eszköze többnyire a SWOT analízis (Asworth-Voogd 1997).

London esetében egy felmérés feltárta, hogy a gazdasági társaságok - mint a legföbb fogyasztók - a föváros központi szerepét tartják a legfontosabbnak. Olyan helynek találták a várost, ahol üzleti kapcsolatokat epíthetnek ki, és professzionális szolgáltatásokat találnak. Az infrastruktúra (légi közlekedés, szállítás, kommunikáció) mellett megemlitették a kultúrát, a szabadidős tevékenységeket és a toleranciát. A negatív jellemzök közül kiemelték: a környezetszennyezést, a zsúfoltságot és a képzettségi színvonal problémáit.

A London Pride Partnership szervezet meghatározta a prioritásokat, amelyek révén megoldhatja ezeket a problémákat, illetve felvázolták azt a jövőképet, melyet el kívánnak érni.

Egy emberi léptékủ, biztonságos várost kínálnak a lakosok számára, ahol a megfizethetö közlekedési rendszer kapcsolja össze a városi(as) falvakat ${ }^{2}$, és ahol az emberek világszínvonalú életminöség szerint élhetnek. Newcastle image elképzelései is hasonló elemekböl építkeznek (élhető város, városias falvak hálózata, multifunkcionalitás, új életstílus) (Healey et al. 1992).

Az európai periféria közepes méretü városai szintén magukévá tették az emberi lépték, az élhetöség, a harmonikus fejlődés illetve a közösségi terek és a participációs technikák eszméjét, amelyet Budapest fejlesztési koncepciójának megalkotói is beépítettek terveikbe.

A deindusztrializáció folyamatának eredményeként a hangsúly a termelésorientált tevékenységekről a fogyasztás-orientált tevékenységekre tevődött. A városok minősége - a fizikai, társadalmi és kulturális infrastruktúra tekintetében - a termelési tényezőkkel azonos fontosságra tett szert. Meghatározóvá vált az ún. 
„puha infrastruktúra” jelentősége (Rechnitzer 1995), a városok az életminőség javítására és új életstílusok előállitására koncentrálják eröfeszítéseiket.

Természetesen, a nagy nyersanyag- és energia-igényü gazdasági ágazatok esetében a hagyományos telepítỏ tényezők jelentősége nem változott, bár a szállitási költségek csökkenése révén ebben a körben is kisebb eltolódások történtek (pl. kőolaj-feldolgozás a kikötőkben).

\section{A niche megtalálása}

A gyengeségek, erősségek, a lehetőségek illetve kockázatok feltárása után kijelölésre kerül a gazdaság azon szegmense (niche), amelyben az adott terület, település megtalálhatja számításait.

A nagy világvárosok számára, mint New York vagy Párizs ez egyszerúbb, mivel a gazdaság és társadalom majd minden területén versenyezhetnek, míg a kisebb városoknak szerényebb lehetőségek kínálkoznak.

London niche-je is meglehetösen széles, a város nemcsak Európa vezetö üzleti központja és a média, a tudomány fellegvára, hanem a különböző intézmények és nemzetközi hálózatok kommunikációs központja is. A London Pride Prospectus szerint London a vállalkozó kedv és kreativitás „erőmüve”, illetve a divat, a müvészetek és a kultúra kiemelkedỏ centruma. Mindezen területeken versenyeznie kell, viszont ki tudja használni a multi-funkcionalitásból eredö összes szinergikus hatást.

Atlanta helyzete sok szempontból eltérö, mivel hiányzik a történelmi háttér, a jellegzetes karakter, képes viszont átalakulni és átformálni arculatát. Erőteljes, virágzó iparára illetve közlekedési és kommunikációs központi szerepkörére alapozva a „Dél Lelkeként" (Rutheiser 1996) igyekeznek bemutatni a várost. Egy nemzetközi befolyással rendelkező, szolgáltatás-központú információs metropolisz képét sugározzák a fogyasztók felé. Az Olimpia jó lehetőséget biztosított, hogy reklámozzák ezt az image-t és megragadják a világ, különösen a döntéshozók figyelmét.

Barcelona esete hasonló a menedzsment eszközök használata tekintetében (Marshall 1996), de a szint alacsonyabb, hiába rendelkezik központi szerepkörrel mint nemzetközi hálózatok csomópontja és multinacionális cégek „fơhadiszállása”, befolyása csupán a Földközi-tenger térségében jelentös.

A negyedik szinten olyan városok találhatók, amelyek kontinentális és regionális szinten keresik niche-jüket. Poszt-fordista, fogyasztói típusú városokká igyekeznek átalakulni. Newcastle célja például az „Észak Milánójává” válni (Healey et al. 1992, 178), megtartva regionális ipari és kulturális központ szerepkörét, közben javítva a nyújtott szolgáltatások minöségét.

Más városok is küzdenek a hanyatló ipar negatív image-ével (Glasgow, Lille). Ook a szolgáltató szektorra, kultúrára és az élet minőségére helyezik a hangsúlyt, ettöl remélve a kitörést, a hanyatlás spiráljának megszakítását.

Perugia környezeti, mủvészeti és kulturális erőforrásait (Nemzetközi Egyetem, események) igyekszik kamatoztatni, míg Siena a turizmus mellett a kutatási és mủvészeti tevékenységre épít (Visions...1994, 174). Mások kulturális öroßkségulket 
kihasználva turisztikai, történelmi várossá próbálnak alakulni, mint pl. Portsmouth és Alicante.

Az utóbbi földrajzi fekvése előnyeit is igyekszik kihasználni, úgy határozva meg önmagát mint egy megkerülhetetlen csomópontot a konszolidált északi és a fejl ödö déli területek között (Visions...1994, 84). Budapest is hasonló csomóponti és közvetítői szerepet kíván betölteni „Nyugat- és Kelet-Európa” között.

\section{Marketing módszertan}

A módszertan tisztán a fogyasztási cikkek marketingjéb ől származtatható, bár vannak bizonyos eltérések.

Miután a niche meghatározásra került, minden eröfeszitést a pozícióba kerülésre kell koncentrálni. A fó feladat egy pozitív image kialakitása annak érdekében, hogy a város nevét egy márkanévvé, a min őség biztosítékává tegyék. A termék- és árpolitika nehezebb alakíthatósága miatt a különböző promóciós eszközök állnak ehhez leginkább rendelkezésre.

Szükség van hangzatos jelszavakra, szlogenekre, hogy magukra vonják a potenciális fogyasztók figyelmét. Fontos, hogy az üzenet igaz, hihetö, vonzó, rövid és megkülönböztető legyen. Meg kell gyöznie a piacot arról, hogy az a terület a legkedvezöbb a befektetésre, vásárlásra, pihenésre stb. A jelszavak egy része megl ehetősen találó, mások igen sután hangzanak. Atlanta az „Álmok városának”, New York - kissé kétértelmúen - „Az Új Világ Fővárosának” tartja magát.

Barcelona szerényebben csak a „Földközi-tenger fövárosának” szeretné láttatni magát. Portsmouth tengerész múltjából fakadóan a hajózáshoz kapcsolódó jelszót választott: „A tengeri Anglia Zászlóshajója” (Asworth-Tunbridge 1990). A hazai példák közül Székesfehérvár emelhető ki, amely „A lehetőségek városaként” hirdeti magát, míg Pécs „kooperatív partner"-ként. Van jó néhány kevésbé szellemes jelszó, mint pl. „Manchester - It's magic” (Ez Varázslat), Leeds - „Szeretni fogod”, vagy Detroit - „A reneszánsz város” (Healey et al. 1992, 208).

A kampányok a városok megismertetésének egy másik eszközét kínálják. Általában a döntéshozókat, véleményformálókat, az üzleti szférát célozzák meg, de célcsoport lehet a lakosság is. A városmarketing szervezetek bevetnek egy sor technológiát, beleértve a reklám irodalmat, televíziót, rádió- és sajtóhirdetést és a PR tevékenységet. A vezérprojektek (flagship projects) reklám szerepe sem kevésbé lényeges.

A marketing szervezetek az image külső eladása mellett fontosnak érzik, hogy pozitív önképet mutassanak a helyi közösségnek, hogy azok lokálpatriotizmusát erősítsék ${ }^{3}$. Ezek az image-k - a posztmodern nagyváros - kényelmes városi(as) falvak futurisztikus, nagyra törö vizióit vetítik elénk. A kultúrára és az életminőségre helyezik a hangsúlyt.

A hely státusza (mint pl. müvészeti város) egyre fontosabbá válik az üzleti vállalkozások telephely választásában („Róma, az örök város”, „Arany Prága”). A fejlesztési ügynökségek a kulturális, történelmi gyökerek megtalálására törekszenek, 
még ha ilyenek nincsenek is. A hagyomány feltalálása a következménye ennek. Atlanta, pl. az „Elfújta a szél” c. regényre és a „Fekete Mekka” örökségre építi image-t. Sikeresebben próbálkozik Birmingham a nehézipari örökség ,újrahasznosításával", létrehozva a Fekete-vidék Múzeumot (Black Country Museum).

A vezérprojektek szintén a város-megújitás általánosan használt eszközei. Jelentös presztízsü, nagyra törő terület- és ingatlan-fejlesztések tartoznak ide, melyek meghatározó katalitikus szerepet játszanak. A szűkös (erö)forrásokat egy szimbólum, egy jelkép létrehozására összpontosítják, amely - feltételezésük szerint - mágnesként vonzza a további beruházásokat, és használatával jobban reklámozhatják a helyet, mint más marketing eszközökkel.

A különböző események szintén kulcsszerepet játszhatnak az image kialakításában, amelyek a nemzetközi média fejlödésének köszönhetően egyre szélesebb és szélesebb publicitást kapnak.

Az Olimpiák a történelem legnagyobb eseményei békeidöben, igy érthetö, hogy a városok ádáz harcot folytatnak a rendezési jog megszerzéséért. Atlanta revitalizációs terveinek katalizátoraként tekintett rá, míg Barcelonában beindította a gazdasági növekedést. Más jelentős sportesemények, mint a világbajnokságok, nemzetközi tornák állomásai szintén a városokra irányíthatják a világ figyelmét, jobb reklámot teremtve nekik, mint bármilyen más hirdetés.

Nemcsak a sportesemények játszanak ilyen szerepet, hanem a nemzetközi konferenciák is, amelyek szintén lehetöséget kínálnak a város megismertetésére (ld. Helsinki, Davos, Reykjavik). A nemzetközi vására révén vált ismertté Hannover, Lipcse, Frankfurt és Sevilla neve. Zenei kulturális események miatt foglalkozik a média olyan városokkal, mint Rio de Janeiro vagy Salzburg. Magyarországi léptékben ilyen lehet például Debrecen, ahol a virágkarnevál vonz sok látogatót (Kozma 1995).

Az „eladók” a fent említett promóciós eszközök alkalmazásával mind a fogyasztók (lakosok, befektetők) befolyásolására törekszenek. A módszer szerint két fajtája lehet ezeknek, az egyik az értelemre igyekszik hatást gyakorolni, míg a másik az érzelmekre (Áts 1994).

A városmarketing szempontjából a feladat tehát hasonló, mint a fogyasztási cikkek esetében: megtalálni a célcsoport megnyerése szempontjából legcélravezetöbb (marketing) stratégiát, és kialakitani a fenti (és a fent nem említett eszközök) lehetö legideálisabb kombinációját (marketing-mixét), amely alkalmas a célok megvalósítására.

\section{A városmarketing hátrányai}

A figyelem a városok egésze helyett azok bizonyos, kitüntetett részeire (zónák, övezetek és projektek) irányul. Az általuk teremtett image nem tudja teljes egészében átfogni a város sokszínüségét, szelektálniuk kell, kiemelve egy-egy vonást, amelyet előtérbe kívánnak helyezni. A gyakorlatban ez a vezérprojektek terjedésében nyilvánul meg, amely a források illetve az eröfeszitések elaprózásához vezet 
(Healey et al. 1992, 202). A stratégia és tervezés hiánya a fejlesztés hatékonyságát rontja, a fejlődés esélyeit határolja be bizonyos szempontból.

\section{Az elosztás és a hozzáférés problémája}

A legfőbb kérdés ugyanaz, mint a fogyasztási javak elosztása esetében: kinek juttassunk és mit? A marketing szemlélet a szabad piac törvényeinek urbanizációra való kiterjesztését jelenti. A megtermelt haszon azonban - a piac automatizmusainak következtében - nem egyenletesen és föleg nem méltányosan oszlik el.

A városmarketing kezdeményezései inkább a befektetök érdekeire koncentrálnak, és kevesebb figyelmet fordítanak a meglévö lakosokra és eszközökre. A hangsúlyt különleges infrastruktúra beruházásokra helyezik, mint pl. konferenciaközpontok, hotelek és repülőterek létrehozása.

A vízparti fejlesztések Glasgowban (Merchant City) új lakóegyütteseket teremtettek, de ezzel a fiatal, középosztálybeli és magasabb jövedelmü csoportokat célozták meg (Healey et al. 1992, 144). Hasonlóan a londoni Docklands-beli lakásépitések sem fizethetők meg akárki számára, illetve megemelték az albérletek és telkek árát megnehezítve a kisvállalkozások és a helyi lakosság életét.

A vezérprojektek nem enyhítenek a foglalkoztatási gondokon sem, mivel többnyire kis számú jól fizetett és sok rosszul fizetett részmunkaidős állást hoznak létre. Gyakran a városközpontra koncentrálnak, nem hozva változást a (hanyatló) külső kerületek számára. A periférikus ingatlanokról nehezen érhetök el az így létrehozott létesítmények. Nem integrálódnak szervesen a város szövetébe, nem válnak részévé a város életének.

Atlanta esetében az Olimpia sem tudta megváltoztatni a város meglévő - „lyukas fánk” - szerkezetét, mivel a központi mag továbbra is hanyatlik. Az „Olimpiai Gyürü" a belvárosban nem generált növekedést, csak a fehérek lakta elővárosokban. Minimális közberuházás maximális magánhasznot eredményezett (Rutheiser 1996).

\section{A közberuházások prioritásainak eltéritése}

A marketing erőfeszitések elvonhatnak olyan pénzügyi és emberi forrásokat, amelyeket fejlesztésekre kellene felhasználni, és amelyekre sokkal nagyobb szükség lenne. Bradford, pl. az oktatási és szociális kiadásokat kurtította meg annak érdekében, hogy turisztikai célpontként reklámozhassa magát (Healey et al. 1992). Londonban a legfőbb cél a repülőtér kapacitásának növelése illetve a hozzá vezetö utak kiépítése, fejlesztése, miközben a tömegközlekedésre kifejezetten ráférne a felújítás.

A marketing eszközök alkalmazásának költségei elvonják a forrásokat a lényeges feladatoktól (sok esetben kevésbé hasznos beruházásokra), miközben pl. a szociális jólét megteremtésére nem marad kapacitás. A relatíve rossz anyagi helyzetben lévő magyar önkormányzatok esetében még élesebben vetódik fel a kérdés, ugyanis húsbavágó döntéseket kell hozni, és megszorításokat alkalmazni egy-egy ilyen marketing-jellegü beruházás megvalósítása érdekében. 


\section{A legitimitással kapcsolatos problémák}

A marketing szervezeteknek a hatékony müködéshez a változó igényekre adott gyors válaszokra illetve gyors és megkérdőjelezhetetlen döntésekre van szüksége. Biztonsági okokból hasznosabb a nyilvánosságot kizárni, így a helyi lakosok elvesztik az ellenőrzést az életüket érintő ügyek felett.

Veszélybe sodorná a szervezet döntéshozó képességét, ha nyilvános vitára bocsátanák a kérdéseket. A megbeszélés hiánya nemcsak a lakosokat érinti hátrányosan, hanem a fejlődés szerkezetét is, mivel megszünik a tervek és a kezdeményezések összhangja, elmarad a harmonizálásuk.

A marketing orientált tervek, még ha tartalmaznak is szép célkitủzéseket a lakásállomány, a közlekedés fejlesztésére illetve a környezet védelmére, háttérben maradnak, illetve ezek lesznek az elsők, amelyek nehézségek esetén kiesnek, mivel - a nyilvánosság mellózése miatt - nem lesz olyan, aki küzdjön megvalósításukért.

A hazai gyakorlatban egyébként is ritka a partnerség kiépítése, a lakosság bevonása. A tervezési folyamatot, a fejlesztési döntések meghozatalát egyfajta „titokzatosság" veszi körül, részben a spekulációtól való félelemböl, részben a „szakmai szempontok" fokozott szem elött tartásából fakadóan. A lakosság bevonása tehát eredendően nehézkes a részvételi technikák fent vázolt kialakulatlansága, másrészt a lakosság meglehetős érdektelensége miatt, így a nyilvánosság kizárása fokozottan veszélyes lehet.

\section{A zéró összegü játék}

Az utánzás, a másolás igénye elnyomhatja a racionális tervezést, illetve sablonos modellek elburjánzásához vezet.

Az Egyesült Államokban jó néhány város épített ki vízparti fesztivál piacteret, amely így elvesztette különleges vonzerejét, miközben a müvészeti, kulturális szolgáltató centrumok gyorsabban gyarapodtak, mint az igények és a repertoár. Az Egyesült Királyságban a városok regionális szintü intézmények (pl. színházak, koncerttermek) vagy különlegességek (pl. Chinatown) létrehozására törekszenek.

A külföldi befektetők vonzása érdekében a magas életszínvonalat kínáló, markáns vállalkozói attitủddel jellemezhetö, progressziv üzleti helyszínek állott és fantáziátlan image-t reklámoznak (Healey et al. 1992). Mivel minden város alkalmazni akarja és fogja a marketing eszközöket, továbbá ugyanazokat a célcsoportokat igyekeznek befolyásolni, az image megszunnik differenciáló tényezỏ lenni, tehát nem érnek el semmit. A verseny, amelyben turisztikai célpontként vagy gyülekezési ${ }^{5}$, kulturális központként próbálják eladni magukat, egy zéró összegũ játékhoz vezet.

Magyarországon - a külföldi beruházók megnyerése érdekében - inkább az élénk vállalkozói környezetet és az olcsó és képzett munkaerōt, illetve a különbözö kedvezményeket igyekeznek a városok kihangsúlyozni. Kiemelik természetesen a kedvezö fekvést, a jó elérhetóséget vagy a kellemes klímát is, ha ezek adottak. Szerepük szerint inkább csak „díszítő”, színesítő elemként adódnak a fö mondanivalóhoz, 
részben annak függvényeként, hogy mennyire számít az adott település turisztikai központnak.

A hasonló célcsoportoknak ajánlott hasonló „termékek”, szolgáltatások itt is egy zéró összegú játék kialakulásához vezethetnek, miközben a befektetók - a város számára - külső tényezők által vezérelve, előre meghatározott prioritás-rendszerek alapján hozzák meg beruházási döntéseiket.

\section{A kulturális uniformizálódás veszélye}

A városoknak - az új image „csomagolása” érdekében - a városi örökség sokszínüségét, gazdagságát és komplexitását néhány látványos és eladható jellemvonásra kell redukálniuk. Nottingham pl. így lett kizárólag Robin Hood városa.

Néha többféle örökség is fellelhető egy-egy városon belül (pl. Jeruzsálem, Libanon, Isztambul esetében), megnehezítve annak eldöntését, melyiket helyezzék elötérbe. Elöfordulhat az is, hogy a kiválasztott image zavarja a helyi lakosok érzékenységét (ld. rabszolga-kereskedelem múzeumai Afrikában) (Asworth-Tunbridge 1990).

$\mathrm{Az}$ eredeti építészeti, kulturális örökség védelme érdekében a tömegturizmus számára csak élethü másolatokat mutatnak be (Akropolisz, Stonehenge). A sokféleség csökkentése és a másolatok bemutatása egy hamis image kialakulásához vezet, nemcsak a turisztikai célpontnak számító történelmi városoknál, hanem minden marketing stratégiát alkalmazó város esetében.

\section{Következtetések}

A marketing szemlélet figyelemre méltó lehetőségeket és előnyöket kínál a városok versenyében részt vevő települések számára, de azon képessége, hogy megoldja a mélyen gyökerezö gazdasági-társadalmi fejlettségi problémákat, illetve, hogy a megtermelt profitot, javakat egyenletesen ossza el, meglehetösen kérdéses.

A szakszerủen alkalmazott marketing stratégiának azonban jelentős szerepe lehet a városi gazdaság visszafejlődési spiráljának megtörésében, elősegitve a városok image-ének javítását és fogyasztásának növelését. Ilyen értelemben mindenféleképp hasznos, sőt lehet, hogy szükséges, viszont önmagában semmiképp nem elegendő.

Mivel a városok versenyéböl nem lehet kiszállni, illetve ebben az „arénában” a szabályokat a piac határozza meg, a városoknak - valamilyen mértékben - mégis fel kell vértezniük magukat a város marketing és image-formálás eszközeivel is, máskülönben könnyen a hanyatlás útjára lépnek.

A magyar vărosok ugyanígy kénytelenek beszállni a városok versenyébe, és részt venni az eröforrásokért, a funkciókért és nem utolsó sorban a lakosokért folytatott küzdelemben.

Magyarország esetében azonban sokkal kisebb a nagyságrend, hiszen Budapesten kívül egyetlen világvárosi méretü település sem található az országban, de regionális központjaink esetében megfigyelhető egyfajta marketing tudatosság kialakulása. 
A városmarketing koncepciók vagy irodák létrehozása már egyértelmủen ebbe az irányba mutat. Az ismertetỏ kiadványok készítése már általános gyakorlattá vált, sőt megyeszékhelyeink mindegyike megjelent az Interneten, többségük a saját városneve alatt szerepel.

A magyar városok esetében is relevánsnak tekinthetők a korábbi konklúziók. A városmarketing bizonyos mértékig kétségtelenül hozzájárul az életkörülmények a gazdasági, társadalmi feltételek javulásához, mozgósítja a város anyagi és szellemi eröforrásait. Tisztán kell azonban látni, hogy a marketing a városfejlesztésnek csupán egyik eszköze lehet, nem szabad tőle (és csak tőle) várni a település felemelkedését.

A város mint rendszer nem csak gazdasági funkciókkal bír, és nem kizárólag gazdasági alapon szerveződik, így vannak társadalmi alrendszerek, ahol nem lehet a marketing szemlélet kizárólagosságát érvényre juttatni.

A magyar városok esetében ez még nem akkora veszélyforrás, ugyanis csak minimális mértékben jellemzi a települési önkormányzatokat bármiféle vállalkozói attitüd, még kevésbé marketing közelítés, így még jelentős lehetőségek rejlenek a városmarketing alkalmazásában.

\section{Jegyzetek}

'A niche szót itt olyan értelemben használjuk, amely egy olyan élettérre, „résre” utal, ahol egy vállalkozás megtalálhatja múködésének feltételeit. Kiterjesztve ez a városokra is igaz lehet.

${ }^{2}$ Az eredeti angol nyelvü forrásmunkákban az „urban villages” kifejezés szerepelt, amelyet jobb hijản 'városias falunak' fordítottunk.

3

Szükség van minderre azért is, hogy... erösiteni lehessen a 'MI' érzést." (Áts 1994, 59)

${ }^{4}$ Minél nehezebb egy termék objektív adottságainak, tulajdonságainak a megkülönböztetése, annál erősebben nyomulnak elötérbe az irracionális képzetek és érźsek (Totth 1994).

${ }^{5}$ Az eredeti angol nyelvủ szakirodalomban a 'convention' szó szerepelt, amelyet leginkább talán „gyülekezésinek" lehetne fordítani.

\section{Irodalom}

Asworth, G.J.-Voogd, H. (1997) A város értékesitése. Marketingszemlélet a közösségi célú várostervezésben. Budapest, Közgazdasági és Jogi Könyvkiadó.

Ashworth, G.J.-Tunbridge, J. E. (1990) The Tourist-Historic City, London, Belhaven.

Áts Zs. (1994) Önkormányzatok marketing-kommunikáciojja. - Marketing. 1. 59-62. o.

Barta Gy. (1998) Nemzetköziesedés, globalizáció, nemzetközi városok. Budapest - nemzetközi város. Glatz F. (szerk.), Budapest, MTA. 13-25. o.

Enyedi Gy. (1995) Városverseny, várospolitika, városmarketing. - Tér és Társadalom. 1-2. 1-3. o.

Enyedi Gy. (1998) Budapest - kapuváros. Budapest - nemzetközi város. - Glatz F. (szerk.), Budapest, MTA. 47-55. o.

European Foundation for the Improvement of Living and Working Conditions. (1994) Visions and actions for medium-sized cities. Office for Official Publications of the European Communities.

Healey, P. et. al. (1992) Rebuilding the City. London, Spon.

Kozma G. (1995) A debreceni önkormányzat első lépései a városmarketing területén.- Comitatus. 5. 15-21. o.

Kozma G. (1999) A városmarketing elemeinek alkalmazása Debrecenben a rendszerváltás után. Debrecen, Studia Geographica.

Marshall, T. (1996) 'Barcelona - fast forward ? City entrepreneurialism in the 1980s and 1990s'. European Planning Studies. 2. 147-165. o.

Piskóti I.-Dankó L.-Schupler H.-Büdy L. (1997) Régió és településmarketing. Miskolc. 
Rechnitzer J. (1995) Vázlatpontok a településmarketing értelmezéséhez és kidolgozásához. - Tér és

Társadalom. 1-2. 5-16. o.

Rutheiser, C. (1996) Imagineering Atlanta. Verso.

The London Pride Partnership. (1994) London Pride Prospectus.

Töröcsik M. (1995) Település- és területidentitás kialakítása marketingeszközökkel. - Tér és Társadalom. 1-2. 17-23.

Totth G. (1994) Milyen képet vágjunk? - Marketing. 4. 292-294. o.

\section{SOME QUESTIONS ON CITY MARKETING}

\section{TAMÁS GORDOS}

Due to the globalisation of world economy, countries - just like their regions and their cities - are forced to increase their competitiveness. They need powerful methods to (re)gain advantages and (re)position themselves. The city marketing seems to solve these problems by the use of marketing techniques well known from the trade of consumer products.

The question is whether they are capable of reaching these aims, and if so, to what extent, and if not why they fall short of expectations.

In my essay I focus on the analysis of marketing tools and methods with a special attention given to the involvement of Hungarian cities. The attention is drawn to problems stemming from an inappropriate use of marketing tools, like the fragmentation of efforts, deterioration of public spending priorities, problems of redistribution of access, problems of accountability, the risk of cultural standardisation, and processes leading to a zero sum game.

It can be concluded that the marketing approach offers considerable opportunities and benefits to cities in inter-urban competition, but its ability to tackle deep-seated economic problems and distribute benefits fairly is quite questionable.

In the case of Hungarian towns and local governments these problems are not that acute, since most of them can not be characterised by any sort of entrepreneurial attitude, nor with a marketing-led approach, so there is still the place for the utilisation of marketing tools. 